\title{
Genetic Analysis of Leaf Rust Resistance in Six Durum Wheat Genotypes
}

\author{
Alexander Loladze, Dhouha Kthiri, Curtis Pozniak, and Karim Ammar
}

First and fourth authors: Global Wheat Program, International Maize and Wheat Improvement Center (CIMMYT), Apdo. Postal 6-641, 06600 Mexico, D.F., Mexico; and second and third authors: Crop Development Centre, Department of Plant Sciences, University of Saskatchewan, 51 Campus Drive, Saskatoon, SK S7N 5A8, Canada.

Accepted for publication 22 May 2014.

\begin{abstract}
Loladze, A., Kthiri, D., Pozniak, C., and Ammar, K. 2014. Genetic analysis of leaf rust resistance in six durum wheat genotypes. Phytopathology 104:1322-1328.

Leaf rust, caused by Puccinia triticina, is one of the main fungal diseases limiting durum wheat production. This study aimed to characterize previously undescribed genes for leaf rust resistance in durum wheat. Six different resistant durum genotypes were crossed to two susceptible International Maize and Wheat Improvement Center (CIMMYT) lines and the resulting $\mathrm{F}_{1}, \mathrm{~F}_{2}$, and $\mathrm{F}_{3}$ progenies were evalu-

cated that most genotypes carried single effective dominant or recessive seedling resistance genes; the only exception to this was genotype Gaza, which carried one adult plant and one seedling resistance gene. In addition, it was concluded that the resistance genes identified in the current study were neither allelic to $L r_{\text {Camayo }}$ or $L r 61$, nor were they related to $L r 3$ or $L r 14 a$, the genes that already are either ineffective or are considered to be vulnerable for breeding purposes. A complicated allelic or linkage relationship between the identified genes is discussed. The results of the study will be useful for breeding for durable resistance by creating polygenic complexes.
\end{abstract} ated for leaf rust reactions in the field and under greenhouse conditions. In addition, allelism tests were conducted. The results of the study indi-
Additional keywords: adult plant resistance, Triticum turgidum.
Durum wheat (Triticum turgidum L.) is an important cereal grain crop, grown primarily around the Mediterranean Basin but also cultivated in Central India, Mexico, Canada and, to some extent, in the United States and Australia. In most of its growing area worldwide, its yield and quality can be significantly affected by leaf rust, caused by Puccinia triticina Erikss. Up to U.S.\$40 million in losses were reported in the state of Sonora, Mexico during the 2008-09 growing season alone (11).

Controlling rust through breeding for resistance is far more cost effective and environmentally friendly than through fungicide application. However, breeding for resistance requires constant identification, characterization, and deployment of new resistance genes or gene combinations because new virulent races of the pathogen, which can overcome single race-specific genes, evolve rapidly (11).

The race $\mathrm{BBG} / \mathrm{BN}$, appearing in Mexico in 2001, has overcome the resistance of more than $85 \%$ of International Maize and Wheat Improvement Center (CIMMYT)'s durum lines as it acquired virulence for $L r_{\text {Altar }}$, recently designated as $L r 72$, a gene present in a number of modern durum germplasm $(8,11,20)$. Since then, CIMMYT has initiated a vigorous resistance breeding effort and, by 2007, extensive collections of widely resistant durum germplasm ready for global distribution were developed. During the same period, the genetic basis of the resistance present in the CIMMYT durum germplasm was investigated and resulted in the identification of $L r 3$ and the $L r 3$-linked gene $L r_{\text {Camayo }}$, both located in chromosome 6BL $(7,10) ; \operatorname{Lr} 27+31$, located in chromosomes 3BS and 4BS, respectively $(19,21,22) ; \mathrm{Lr} 14 a$, located in chromosome 7BL (6); and Lr61, located in chromosome 6BS (5). Most of these genes are gradually becoming ineffective for use in

Corresponding author: A. Loladze; E-mail address: a.loladze@cgiar.org

http://dx.doi.org/10.1094/PHYTO-03-14-0065-R

(c) 2014 The American Phytopathological Society a monogenic state in different parts of the world. Although still effective around the Mediterranean Basin, in East Africa, and in South Asia, the complementary gene pair $L r 27+31$ was overcome by Mexican race BBG/BP in $2008(11,12)$, which has become the predominant race affecting durum wheat in the country.

Gene $\operatorname{Lr} 3$ also remains effective in the abovementioned regions but virulence for this gene has been identified in Mexico (race $\mathrm{CBB} / \mathrm{BN}$ ) (J. Huerta-Espino, personal communication), even though it has not been detected again in farmers' fields. However, if $L r 3$ is deployed on a large scale, it may result in the increased incidence of virulence for the gene. Similarly, a race designated as BBB/BN_Lr61Vir virulent for Lr61 was detected in Mexico only once in 2010 (8). Being avirulent for $\operatorname{Lr} 72$, which is widely present in CIMMYT's durum germplasm, race BBB/BN_Lr61Vir will require further mutation to cause significant losses in Mexico.

Although, in combination with $\operatorname{Lr} 72$, gene $L r 14 a$ still provides resistance in Mexico, East-Africa, and India, it is no longer an effective option around the Mediterranean Basin because virulence for $L r 14 a$ in durum wheat was identified in the south of France (4) and has overcome the resistance of many Mediterranean landmark durum cultivars (3). Furthermore, virulence for the combination of LrI4a and Lr72 in durum wheat has been recently detected in Spain (I. Solis, C. Royo, and D. Villegas, personal communication) and Tunisia (2). The over-reliance on this gene combination in all germplasm groups worldwide raises an immediate and strong concern of global genetic vulnerability in durum wheat in relation to leaf rust. The availability of molecular markers gwm 344 and gwm 146 made possible the close-to-diagnostic detection of LrI4a in durum wheat $(6,13,14)$ and has allowed the characterization of ample germplasm collections, which indicated that a considerable number of lines developed at CIMMYT since 2001 relied to a great extent on this single gene for their resistance. Of the 1,328 advanced breeding germplasms screened, 1,264 (95\%) likely carried Lrl4a (K. Ammar 
and S. Dreisigacker, unpublished data). A similar situation was observed with germplasm originating from the International Center for Agricultural Research in the Dry Areas (ICARDA), where approximately $85 \%$ of a smaller set of lines tested also might have carried $\operatorname{LrIHa}$ (14).

In this context, widening the global genetic diversity of leaf rust resistance in durum germplasm is urgently required. The present study was conducted to characterize the genetic basis of leaf rust resistance in six durum genotypes, previously demonstrated to be resistant in various international locations, and assess their usefulness in broadening the genetic diversity for leaf rust resistance of CIMMYT durum germplasm.

\section{MATERIALS AND METHODS}

Characterization of leaf rust resistance inheritance. Field evaluation. Resistance sources, selected for their low seedling and adult plant infection types (ITs) at multiple locations worldwide, included the Middle-Eastern line Gaza; the Moroccan 'Amria'; the ICARDA lines Geromtel_3, Geruftel_1, and Tunsyr_2; and the French 'Byblos' (Table 1). Mexican 'Atil C2000' and line Atil*2/Local Red were used as susceptible parents. Atil C2000 is known to carry the ineffective gene $\operatorname{Lr} 72$ (8), while Atil*2/Local Red does not carry any known or detectable resistance genes (J. Huerta-Espino, personal communication).

Crosses between resistant and susceptible parents were made in all combinations at CIMMYT's Centro Experimental de Norman E. Borlaug (CENEB) station in Cd. Obregon, Sonora, during spring 2010. The resulting $F_{1}$ plants were space planted and grown at CIMMYT's El Batan experimental station (state of Mexico) during the summer of the same year. Three individual $F_{1}$ plants from each cross were harvested and the resulting seed was sown as three individual $\mathrm{F}_{2}$ subpopulations per each cross. These were space planted at CENEB during winter 2011 in 10-m-long double rows under fungicide treatment for advancement to the $F_{3}$ generation without losing plants due to heavy rust infection. In addition, a duplicate set of all $\mathrm{F}_{2}$ subpopulations was sown under rust inoculation to determine $F_{2}$ segregation ratios. Each $F_{2}$ subpopulation arising from an individual $F_{1}$ plant was assessed for segregation separately and, if ratios were similar between the subpopulations of the same cross, data were pooled into a combined dataset. The single $\mathrm{F}_{2}$ plant-derived $\mathrm{F}_{3}$ families were space planted at El Batan in summer 2011 in double 1.2-m-long rows providing opportunity to observe 20 to 30 individual plants per family. Data were again recorded from each $\mathrm{F}_{3}$ family arising from individual $F_{1}$ plants and later pooled. Susceptible 'Banamichi C2004' (resistant to BBG/BN but susceptible to $\mathrm{BBG} / \mathrm{BP}$ ) was used as rust spreader rows for the evaluation of $\mathrm{F}_{1}$ and $F_{2}$ plants and $F_{3}$ families. The parental genotypes were included in all field evaluations.
All plant material and the susceptible spreader rows were inoculated with leaf rust race $\mathrm{BBG} / \mathrm{BP}$, the predominant durum-specific race in Mexico carrying virulence for $\operatorname{Lr} 10, \operatorname{Lr} 11, \operatorname{Lr} 23, \operatorname{Lr} 27+31$, and $L r 72$. The suspension of the urediniospores in light mineral oil (Soltrol 170; 5 to $10 \mathrm{mg}$ of urediniospores per $5 \mathrm{ml}$ of oil) was applied using a hand sprayer at least three times at tillering stage of plant development to ensure strong and uniform infection.

A modified Cobb scale (18) was used for disease scoring in parental genotypes. Disease severity was estimated and recorded as the percentage of leaf area affected by the disease. Host response was recorded as $\mathrm{R}, \mathrm{MR}, \mathrm{MS}$, or $\mathrm{S}$ to denote resistant, moderately resistant, moderately susceptible, and susceptible reactions, respectively (17); when the host response was not clearly defined between MR and MS, letter M was used to record such reactions. The scoring was performed at least twice during the growing season between the early and late heading stages of plant development. $F_{2}$ plants were scored as $R$ or $S$ and $F_{3}$ families were classified as homozygous resistant (Hr), heterozygous or segregating (Het), and homozygous susceptible (Hs). For the analyses of segregation ratio in the $\mathrm{F}_{2}$ and $\mathrm{F}_{3}$ generations, $\chi^{2}$ tests were used to estimate the number of genes involved in the inheritance of leaf rust resistance.

Seedling stage evaluation. In order to determine whether the resistance observed in the field belonged to the seedling or adult plant types, seedlings of $\mathrm{F}_{3}$ families from the crosses between the resistant and susceptible parental lines were inoculated with the same race (BBG/BP) under controlled greenhouse conditions. Approximately 25 to 35 seedlings from each $\mathrm{F}_{3}$ family were grown at 20 to $26^{\circ} \mathrm{C}$ in the greenhouse in 7-by-7-by-10-cm pots, with a soil mix consisting of one part peat moss, one part sand, and one part black soil. Pots were fertilized twice with a urea fertilizer ( $5 \mathrm{~g}$ per 10 liters of water) 4 to 5 days after planting and 2 to 3 days after inoculation. Seedlings were inoculated with urediniospores suspended in light mineral oil (Soltrol 170; 5 to $10 \mathrm{mg}$ of urediniospores per $5 \mathrm{ml}$ of oil) using a hydrocarbon propellant pressure pack. The oil was allowed to evaporate from the leaves for $30 \mathrm{~min}$ before placing the seedlings in a dark mist room at 20 to $22^{\circ} \mathrm{C}$ for 18 to $20 \mathrm{~h}$. Following incubation, plants were transferred to the greenhouse at 20 to $26^{\circ} \mathrm{C}$ under natural light conditions. $\mathrm{F}_{3}$ families were again classified as $\mathrm{Hr}$, Het, or Hs based on their ITs 10 to 12 days after inoculation. The 0 -to- 4 scale was used for scoring parental lines (with 0 indicating completely resistant and 4 representing completely susceptible), as described by McIntosh et al. (17).

Evaluation of adult plant resistance of $F_{3}$ families derived from crosses involving genotype Gaza. Based on the results of the seedling tests, it was suggested that Gaza could have carried at least one adult plant resistance (APR) gene. In order to confirm this hypothesis, 10 selected $F_{3}$ families of the crosses of Gaza with the two susceptible genotypes were grown to the flag leaf

TABLE 1. Origin, pedigree, and selection histories of the durum wheat genotypes used in the study

\begin{tabular}{|c|c|c|c|}
\hline Genotype & Origin & Pedigree & Selection history \\
\hline \multicolumn{4}{|l|}{ Resistance sources } \\
\hline Gaza & Middle-East & Unknown, CIMMYT Genotype ID 233 & \\
\hline Amria & Morocco & Hadj Mouline/Saada//Karim & INRAM.1808 \\
\hline Geromtel_3 & ICARDA & Gersabil_1/4/D68.1.93A.1A//Ruff/Flamingo/3/Omtel_5 & $\begin{array}{l}\text { ICD95.1174-C-2AP-0AP-12AP-0AP-3AP-0AP-12AP- } \\
\text { 0AP-1AP-0AP }\end{array}$ \\
\hline Geruftel_1 & ICARDA & $\begin{array}{l}\text { Genaro T 81/4/D68.1.93A.1A } \\
\text { //Ruff/Flamingo/3/Omtel_5 }\end{array}$ & ICD95.1302-C-3AP-0AP-1AP-0AP-5AP-0AP-5AP-0AP \\
\hline Tunsyr_2 & ICARDA & D68.1.93A.1A//Ruff/Flamingo/3/Omtel_5/4/Lahn & ICD95.0169-C-0AP-2AP-0AP-4AP-0AP \\
\hline Byblos & France & Unpublished & Unpublished \\
\hline \multicolumn{4}{|l|}{ Susceptible parents } \\
\hline Atil*2/Local Red & CIMMYT & Atil*2/Local Red & CGSS04B00073T \\
\hline Atil C2000 & Mexico & Sooty_9/Rascon_37 & CD91B1938-6M-030Y-030M-4Y-0M-0B-0131Y-0MEX \\
\hline \multicolumn{4}{|c|}{ Testers for known genes } \\
\hline$L r_{\text {Camayo }}$ tester & Mexico & CIRNO C2008 = Sooty/Rascon//Camayo & CGSS02Y00004S-2F1-6Y-0B-1Y-0B \\
\hline Lr61 tester & CIMMYT & Sooty_9/Rascon_37//Guayacan INIA & CGSS02Y00011S-2F1-5Y-0B-2Y-0B-2Y-0B \\
\hline
\end{tabular}


stage in the greenhouse, inoculated with the same BBG/BP race, and incubated as described above. The $\mathrm{F}_{3}$ families were selected based on the results of the previous evaluations where, in the field conditions in the adult stage of plant development, they were classified as resistant but later, in the seedling stage, the same families were observed to be susceptible. The number of these $F_{3}$ families was limited to only 10 because of the greenhouse space limitations; the plants had to be grown in individual pots (two to three plants per 20 -cm-diameter pot) with up to 50 plants per $\mathrm{F}_{3}$ family. The ITs of the adult plants were scored as described above for the seedling tests (using the 0-to-4 scale).

Allelism tests. Allelism effects were investigated in $F_{2}$ populations from crosses between all resistant parental lines except those involving Byblos. A minimum of 181 and up to 326 individual plants per each of the 10 resulting $F_{2}$ populations grown under artificially created epidemic conditions in the field with race $\mathrm{BBG} / \mathrm{BP}$ were evaluated at El Batan Experimental Station during summer 2012. In addition, allelism to known resistance

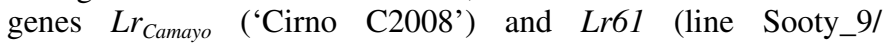
Rascon_37//Guayacan INIA) was studied in $\mathrm{F}_{2}$ populations (177 to 310 individual plants per population). All crosses were generated as described above for the crosses between resistant and susceptible genotypes. Assessments of segregation of leaf rust resistance were conducted under field conditions, as described above. In cases when no segregation for leaf rust resistance was observed in the $\mathrm{F}_{2}$ crosses, it was assumed that the two resistant parents carried the same or very closely linked resistance genes.

\section{RESULTS}

Inheritance of resistance, number of genes involved, and gene action. The ITs of the $F_{1}$ plants of the crosses between Gaza and both susceptible parents were similar to that of Gaza, indicating a dominant mode of resistance gene inheritance in this

TABLE 2. Infection types of parental genotypes and the $F_{1} s$ of the crosses with the two susceptible parents Atil*2/Local Red and Atil C2000 under artificially inoculated field conditions with leaf rust (Puccinia triticina) race BBG/BP at El Batan Experimental Station during summer 2010

\begin{tabular}{llcccc}
\hline & \multicolumn{3}{c}{ Leaf rust infection types } \\
\cline { 2 - 3 } \cline { 5 - 6 } \cline { 5 - 6 } Genotype & \multicolumn{2}{c}{ Parents } & & $\mathrm{F}_{1} \mathrm{~s}$ of the crosses with \\
\cline { 2 - 3 } \cline { 5 - 6 } & $\begin{array}{c}\text { Adult } \\
\text { plants }\end{array}$ & Seedlings & & $\begin{array}{c}\text { Atil*2/ } \\
\text { Local Red }\end{array}$ & $\begin{array}{c}\text { Atil } \\
\text { C2000 }\end{array}$ \\
\hline Gaza & $5 \mathrm{M}$ & $; 1=$ & & $10 \mathrm{M}$ & $10 \mathrm{M}$ \\
Amria & $5 \mathrm{M}$ & $\mathrm{X}$ & & $30 \mathrm{M}$ & $30 \mathrm{M}$ \\
Geromtel_3 & 0 & $; 1=$ & & $5 \mathrm{M}$ & $5 \mathrm{M}$ \\
Geruftel_1 & 0 & $; 1=$ & & $5 \mathrm{M}$ & $5 \mathrm{M}$ \\
Tunsyr_2 & 0 & $\mathrm{X}$ & & $5 \mathrm{M}$ & $5 \mathrm{M}$ \\
Byblos & $5 \mathrm{M}$ & $33+$ & & $50 \mathrm{M}$ & $40 \mathrm{M}$ \\
Atil*2/Local Red & $100 \mathrm{~S}$ & 4 & & - & - \\
Atil C2000 & $90 \mathrm{~S}$ & 4 & & - \\
\hline
\end{tabular}

genotype (Table 2). Field-based segregation ratios of $9 \mathrm{R}: 7 \mathrm{~S}$ in the $\mathrm{F}_{2}$ generation (Table 3 ) of crosses with both susceptible parents suggested the presence of two complementary genes in Gaza $\left(P_{9: 7}\right.$ values $=0.43$ and 0.51 in crosses with Atil $* 2 /$ Local Red and Atil $\mathrm{C} 2000$, respectively). However, the segregation ratio of 7Hr:8Het:1Hs observed in the $\mathrm{F}_{3}$ families $\left(P_{7: 8: 1}\right.$ values $=0.12$ and 0.75 in crosses with Atil*2/Local Red and Atil C2000, respectively) was more consistent with that expected for a combination of one dominant gene and one recessive resistance gene (Table 4). However, the $1 \mathrm{Hr}: 2 \mathrm{Het}: 1 \mathrm{Hs}$ segregation ratio observed in the seedling tests $\left(P_{1: 2: 1}\right.$ values $=0.18$ and 0.68 in crosses with Atil*2/Local Red and Atil C2000, respectively) suggested the presence of only one seedling resistance gene in Gaza; this discrepancy between seedling and adult plant evaluation results, observed in crosses with both susceptible parents, suggested that Gaza could carry one APR gene and one seedling resistance gene. The involvement of an APR gene was verified by selecting $10 \mathrm{~F}_{3}$ families that were uniformly resistant in the field in the adult stage but also uniformly susceptible at seedling stage (ITs of 3+ to 4 ), testing them again at the adult stage (flag-leaf stage) under controlled greenhouse conditions, and, finally, confirming that these families were, indeed, resistant in the adult stage.

The ITs of the $F_{1}$ plants of the crosses between Amria and both susceptible parents were higher than those of Amria but lower than those of the susceptible parent, indicating a partially dominant/recessive mode of inheritance (Table 2). Field-based segregation ratios in the $F_{2}$ generation could fit three possible models, with the $1 \mathrm{R}: 3 \mathrm{~S}$ ratio $\left(P_{1: 3}\right.$ values $=0.12$ and 0.15 in crosses with Atil*2/Local Red and Atil C2000, respectively) indicating the involvement of a single recessive gene and the 3R:13S $\left(P_{3: 13}\right.$ values $=0.98$ and 0.73 in crosses with Atil ${ }^{*} 2 /$ Local Red and Atil C2000, respectively) ratio that could indicate either the presence of two complementary recessive genes or the involvement of two genes, with one suppressing the expression of the other. However, neither of the two-gene models could be retained as plausible when considering field-based segregation ratios and the results from the seedling stage evaluations in the $F_{3}$ generation. Ultimately, the $1 \mathrm{Hr}$ : $2 \mathrm{Het}: 1 \mathrm{Hs}$ segregation ratio of $\mathrm{F}_{3}$ families in both adult plant and seedling stages $\left(P_{1: 2: 1}\right.$ values for adult plant test $=0.19$ and 0.50 in crosses with Atil $* 2 /$ Local Red and Atil C2000, respectively, and $P_{1: 2: 1}$ values for seedling test $=$ 0.18 and 0.52 in crosses with Atil*2/Local Red and Atil C2000, respectively) indicate that Amria is likely to carry a single gene (Table 4).

The high ITs of the $F_{1}$ plants and 1R:3S segregation ratio of the $\mathrm{F}_{2}$ plants of crosses between Byblos and the two susceptible parents $\left(P_{1: 3}\right.$ values $=0.68$ and 0.21 in crosses with Atil*2/Local Red and Atil C2000, respectively) suggest that Byblos carries a single recessive gene (Tables 2 and 3 ). The field-based segregation of $\mathrm{F}_{3}$ families from the same crosses fit the $1 \mathrm{Hr}: 2 \mathrm{Het}: 1 \mathrm{Hs}$ ratio $\left(P_{1: 2: 1}\right.$ values $=0.59$ and 0.78 in crosses with Atil ${ }^{*} 2 /$ Local Red and Atil C2000, respectively), which was also confirmed at

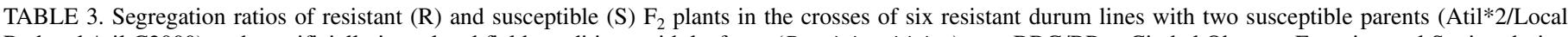

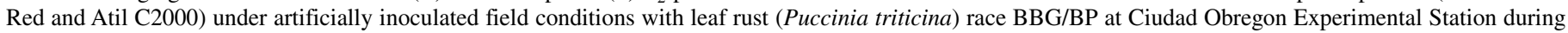
spring 2011

\begin{tabular}{|c|c|c|c|c|c|c|c|c|c|c|c|c|c|c|}
\hline \multirow[b]{3}{*}{ Parent $^{\mathrm{a}}$} & \multicolumn{7}{|c|}{$\mathrm{F}_{2} \mathrm{~s}$ of the crosses with Atil*2/Local Red } & \multicolumn{7}{|c|}{$\mathrm{F}_{2} \mathrm{~S}$ of the crosses with Atil C2000 } \\
\hline & \multicolumn{2}{|c|}{$\mathrm{F}_{2}$ plants $(n)$} & \multicolumn{5}{|c|}{$P$ value for $\chi^{2}$ for different expected ratios } & \multicolumn{2}{|c|}{$\mathrm{F}_{2}$ plants $(n)$} & \multicolumn{5}{|c|}{$P$ value for $\chi^{2}$ for different expected ratios } \\
\hline & $\mathrm{R}$ & $\mathrm{S}$ & $3: 1$ & $1: 3$ & $9: 7$ & $3: 13$ & $13: 3$ & $\mathrm{R}$ & S & $3: 1$ & $1: 3$ & $9: 7$ & $3: 13$ & $13: 3$ \\
\hline Gaza & 61 & 55 & $\ldots$ & $\ldots$ & 0.43 & $\ldots$ & $\ldots$ & 74 & 51 & $\ldots$ & $\ldots$ & 0.51 & $\cdots$ & $\ldots$ \\
\hline Amria & 23 & 99 & $\ldots$ & 0.12 & $\ldots$ & 0.98 & $\ldots$ & 29 & 117 & $\ldots$ & 0.15 & $\ldots$ & 0.73 & $\ldots$ \\
\hline Geromtel_3 & 92 & 32 & 0.84 & $\ldots$ & $\ldots$ & $\ldots$ & 0.04 & 144 & 42 & 0.45 & $\ldots$ & $\ldots$ & $\ldots$ & 0.18 \\
\hline Geruftel_1 & 123 & 33 & 0.27 & $\ldots$ & $\ldots$ & $\ldots$ & 0.44 & $\mathrm{~N} / \mathrm{A}^{\mathrm{b}}$ & - & - & - & $\ldots$ & - & - \\
\hline Tunsyr_ $\overline{2}$ & 104 & 45 & 0.14 & $\ldots$ & $\ldots$ & $\ldots$ & $\ldots$ & 129 & 51 & 0.30 & $\ldots$ & $\ldots$ & $\ldots$ & $\ldots$ \\
\hline Byblos & 30 & 98 & $\ldots$ & 0.68 & $\ldots$ & $\ldots$ & $\ldots$ & 42 & 100 & $\ldots$ & 0.21 & $\ldots$ & $\ldots$ & $\ldots$ \\
\hline
\end{tabular}

a Resistant parent.

b N/A = not available. 
the seedling stage $\left(P_{1: 2: 1}\right.$ values $=0.14$ and 0.74 in crosses with Atil*2/Local Red and Atil C2000, respectively) (Table 4).

The ITs of the $F_{1}$ plants of the crosses between Geromtel_3 and both susceptible parents were as low as those of the resistant parent, which indicate a dominant nature of the resistance gene inheritance in this genotype (Table 2). The segregation ratio observed between $\mathrm{F}_{2}$ plants of the crosses between Geromtel_3 and both susceptible parents best fit a $3 \mathrm{R}: 1 \mathrm{~S}$ ratio $\left(P_{3: 1}\right.$ values $=$ 0.84 and 0.45 in crosses with Atil $* 2 /$ Local Red and Atil C2000, respectively), suggesting that resistance is controlled by one dominant gene (Table 3). However, the observed segregation also fit the 13R:3S ratio in the $\mathrm{F}_{2}$ plants of Geromtel_3 3 Atil C2000 $\left(P_{13: 3}\right.$ value $\left.=0.18\right)$, though the $P$ value for the $\chi^{2}$ test of the $\mathrm{F}_{2}$ plants of Geromtel_3 $\times$ Atil*2/Local Red was only 0.04 . If the $13 \mathrm{R}: 3 \mathrm{~S}$ ratio is considered valid, this would suggest the presence of a dominant epistasis. The $\mathrm{F}_{3}$ segregation ratios of adult plants of the same crosses fit the $1 \mathrm{Hr}: 2 \mathrm{Het}: 1 \mathrm{Hs}$ ratio $\left(P_{1: 2: 1}\right.$ values $=0.23$ and 0.53 in crosses with Atil ${ }^{*} 2 /$ Local Red and Atil C2000, respectively). This was further confirmed in the $F_{3}$ seedlings $\left(P_{1: 2: 1}\right.$ values $=0.12$ and 0.42 in crosses with Atil $* 2 /$ Local Red and Atil C2000, respectively) (Table 4).

The low ITs of the $F_{1}$ plants of the cross of Geruftel_1 and both susceptible genotypes imply a dominant mode of gene action in this cultivar (Table 2). Segregation of $F_{2}$ plants from the cross between Geruftel_1 and the susceptible Atil*2/Local Red fits a 13R:3S ratio $\left(P_{13: 3}\right.$ value $\left.=0.44\right)$, although a fit for the $3 \mathrm{R}: 1 \mathrm{~S}$ ratio $\left(P_{3: 1}\right.$ value $\left.=0.27\right)$ could also be possible (Table 3$)$. Therefore, a situation identical to that of Geromtel_3 was observed for the line Geruftel_1 when considering $\mathrm{F}_{1}$ evaluation results and $\mathrm{F}_{2}$ segregation ratios in the cross with Atil ${ }^{*} 2 /$ Local Red; however, because the $\mathrm{F}_{2}$ plants from the cross with the Atil C2000 could not be evaluated due to insufficient number of $F_{2}$ plants and $F_{3}$ families, further characterization of this resistance source could not be continued.

The low ITs of $F_{1}$ plants of the crosses between Tunsyr_2 and both susceptible parents suggest a dominant mode of inheritance of resistance in this genotype (Table 2). The $F_{2}$ and $F_{3}$ segregation ratios of the cross between Tunsyr_2 and both susceptible parents fit the 3R:1S ( $P_{3: 1}$ values $=0.14$ and 0.30 in crosses with Atil*2/Local Red and Atil C2000, respectively) and 1Hr:2Het:1Hs $\left(P_{1: 2: 1}\right.$ values $=0.44$ and 0.41 in crosses with Atil $* 2 /$ Local Red and Atil C2000, respectively;) ratios, respectively (Tables 3 and 4). This was also confirmed in the $\mathrm{F}_{3}$ seedlings $\left(P_{1: 2: 1}\right.$ values $=$ 0.72 and 0.07 in crosses with Atil*2/Local Red and Atil C2000, respectively). Therefore, the results suggest that Tunsyr_2 carries one dominant gene.

Allelism tests. The presence of susceptible plants in $F_{2}$ populations of all the crosses involving Amria (Table 5) indicates that the latter genotype carries a gene that is different from those of the other resistant parents (except Byblos) and that it is not allelic to either $L r_{\text {Camayo }}$ or $\operatorname{Lr61}$ (Table 6).
No susceptible plants could be identified in the crosses involving Gaza, Geromtel_3, and Geruftel_1, suggesting that the genes from these three resistance sources may be allelic or closely linked (Table 5). However, although the gene from Gaza was not allelic or linked to Lr61, those of Geromtel_3 and Geruftel_1 appeared to be so, as indicated by the absence of susceptible plants in $\mathrm{F}_{2}$ populations from crosses between these genotypes and the Lr61-carrying Sooty_9/Rascon_37//Guayacan INIA (Table 6).

The resistance gene of Tunsyr_2 appeared to be allelic or closely linked with genes from Geromtel_3 and Geruftel_1, and all three genotypes may potentially owe their resistance to $\bar{L} r 61$ or a closely linked gene. However, there was no allelic relationship between Tunsyr_2 and the resistance of Gaza.

Based on the results from crosses with the $L r_{\text {Camayo }}$-carrying Cirno C2008, none of the genes involved in the resistance of the six resistance sources were either allelic or linked to this gene. Finally, although the relationship between the gene in Byblos and those from the other sources could not be determined, it is very obvious that Byblos was not related to either $L r_{\text {Camayo }}$ or $L r 61$ (Table 6).

\section{DISCUSSION}

Leaf rust is present, and can become yield-limiting, in most durum-wheat-growing areas worldwide. Breeding for resistance to this disease is a priority for many breeding programs. Several resistance genes have been identified in CIMMYT durum germplasm (7-11) but most are no longer globally effective or may have time-limited usefulness for global breeding. Furthermore, the over-reliance on $L r 14 a$ in many germplasm groups worldwide puts durum wheat in a situation of genetic vulnerability. Therefore, the identification, characterization, and use of alternative, globally effective, new sources of resistance is re-

TABLE 5. Frequencies of resistant and susceptible $F_{2}$ plants of the intercrosses of the resistant durum genotypes for allelism testing evaluated under artificially inoculated field conditions with leaf rust (Puccinia triticina) race BBG/BP during summer 2012 at El Batan Experimental Station

\begin{tabular}{lccc}
\hline & \multicolumn{3}{c}{ Number of plants } \\
\cline { 2 - 4 } Cross & Total & Resistant & Susceptible \\
\hline Gaza/Amria & 229 & 214 & 15 \\
Gaza/Geromte1_3 & 326 & 326 & 0 \\
Gaza/Geruftel_1 & 231 & 231 & 0 \\
Gaza/Tunsyr_2 & 181 & 177 & 4 \\
Amria/Geromtel_3 & 250 & 220 & 30 \\
Amria/Geruftel_1 & 306 & 268 & 38 \\
Amria/Tunsyr_2 & 304 & 250 & 54 \\
Geromtel_3/Geruftel_1 & 297 & 297 & 0 \\
Geromtel_3/Tunsyr_2 & 275 & 275 & 0 \\
Geruftel_1/Tunsyr_2 & 249 & 249 & 0 \\
\hline
\end{tabular}

TABLE 4. Frequencies of homozygous resistant (Hr), heterozygous (Het), and homozygous susceptible (Hs) $\mathrm{F}_{3}$ families of the crosses of five resistant durum lines with two susceptible parents (Atil*2/Local Red and Atil C2000) under artificially inoculated field conditions with leaf rust (Puccinia triticina) race BBG/BP in the field at El Batan Experimental Station during summer 2011 (adult plants) and in the greenhouse (seedlings) during summer 2012

\begin{tabular}{|c|c|c|c|c|c|c|c|c|c|c|c|c|c|c|c|c|c|c|c|c|}
\hline \multirow[b]{3}{*}{ Parent $^{\mathrm{a}}$} & \multicolumn{10}{|c|}{ Crosses with Atil*2/Local Red } & \multicolumn{10}{|c|}{ Crosses with Atil C2000 } \\
\hline & \multicolumn{3}{|c|}{ Adult plants ${ }^{\mathrm{b}}$} & \multirow[b]{2}{*}{ Ratio $^{c}$} & \multirow[b]{2}{*}{$P^{\mathrm{d}}$} & \multicolumn{3}{|c|}{ Seedlings ${ }^{b}$} & \multirow[b]{2}{*}{ Ratio $^{c}$} & \multirow[b]{2}{*}{$P^{\mathrm{d}}$} & \multicolumn{3}{|c|}{ Adult plants ${ }^{b}$} & \multirow[b]{2}{*}{ Ratio $^{c}$} & \multirow[b]{2}{*}{$P^{\mathrm{d}}$} & \multicolumn{3}{|c|}{ Seedlings $^{b}$} & \multirow[b]{2}{*}{ Ratio $^{c}$} & \multirow[b]{2}{*}{$P^{\mathrm{d}}$} \\
\hline & $\mathrm{Hr}$ & Het & $\mathrm{Hs}$ & & & $\mathrm{Hr}$ & Het & $\mathrm{Hs}$ & & & $\mathrm{Hr}$ & Het & $\mathrm{Hs}$ & & & $\mathrm{Hr}$ & Het & $\mathrm{Hs}$ & & \\
\hline$\overline{\text { Gaza }}$ & 91 & 135 & 18 & $7: 8: 1$ & 0.12 & 63 & 94 & 50 & $1: 2: 1$ & 0.18 & 48 & 62 & 9 & $7: 8: 1$ & 0.75 & 42 & 80 & 47 & $1: 2: 1$ & 0.68 \\
\hline Amria & 48 & 123 & 48 & $1: 2: 1$ & 0.19 & 50 & 123 & 46 & $1: 2: 1$ & 0.18 & 69 & 120 & 70 & $1: 2: 1$ & 0.50 & 69 & 120 & 57 & $1: 2: 1$ & 0.52 \\
\hline Geromtel_3 & 46 & 98 & 35 & $1: 2: 1$ & 0.23 & 52 & 98 & 34 & $1: 2: 1$ & 0.12 & 59 & 136 & 59 & $1: 2: 1$ & 0.53 & 58 & 137 & 58 & $1: 2: 1$ & 0.42 \\
\hline Tunsyr_2 & 43 & 108 & 52 & $1: 2: 1$ & 0.44 & 46 & 99 & 54 & $1: 2: 1$ & 0.72 & 27 & 39 & 21 & $1: 2: 1$ & 0.41 & 40 & 74 & 55 & $1: 2: 1$ & 0.07 \\
\hline Byblos & 60 & 120 & 51 & $1: 2: 1$ & 0.59 & 45 & 125 & 62 & $1: 2: 1$ & 0.14 & 61 & 135 & 61 & $1: 2: 1$ & 0.78 & 59 & 133 & 63 & $1: 2: 1$ & 0.74 \\
\hline
\end{tabular}

\footnotetext{
${ }^{a}$ Resistant parent.

b Number of $\mathrm{F}_{3}$ families.

c Expected ratio.
}

d $P$ value for $\chi^{2}$. 
quired and is currently considered as a priority activity within CIMMYT's durum research agenda. Such sources are sought among cultivars or breeding lines with limited or no relation to CIMMYT germplasm, historical landraces of various geographical origins, wild relative derivatives, and wild relatives themselves. The six resistant genotypes characterized in the present study are but the first of the potentially useful sources identified for in-depth study. They were selected based on the information obtained from various field trials from several locations in Mexico and around the Mediterranean Basin (data not shown). None of these lines appeared to carry $L r 3$ for their resistance because they exhibited low ITs when inoculated with $L r 3$-virulent race CBG/BP; a possibility of $L r 3$ being present in combination with other effective genes would not be likely because five of the durum genotypes segregated for single genes and line Gaza carried one APR and one seedling gene effective against CBG/BP. In addition, none of the lines appeared to carry $\operatorname{Lr} 14 a$, based on results from separate studies conducted with $\operatorname{Lr} 14 a$ virulent races in France (H. Goyeau, personal communication) and at CIMMYT using the Mexican races (A. Loladze and K. Ammar, unpublished data); furthermore, none of these lines carried the molecular markers gwm344 and gwm146, known to be linked to Lr14a (13). Therefore, these lines were considered to be good candidates for exploring alternative sources of resistance, possibly different from those already routinely used in CIMMYT's breeding program.

Although ineffective against most durum leaf rust races common in Mexico, the partially dominant gene $\operatorname{Lr} 72(8,19)$ is still effective against all bread wheat leaf rust races present in the country. A decision was made to investigate the potential interaction effect of this gene on the expression of the genes from the six resistant sources by crossing the latter with a susceptible parent carrying $\operatorname{Lr} 72$ (Atil C2000) in addition to crossing them with Atil*2/Local Red, which did not carry any known or detectable resistance gene. Both susceptible parents yielded the same segregation ratios upon crossing with five of the six resistant parents (Geruftel_1 was not crossed to Atil C2000), indicating that $L r 72$ did not have any detectable effect on the expression of the resistance genes carried by the resistant genotypes when inoculated with BBG/BP. On the other hand, this "duplication" provided additional validation for results obtained from crosses made with Atil*2/Local Red and enhanced the robustness of the inferred conclusions with regards to inheritance and gene numbers involved in each resistant genotype.

All resistant parental genotypes were clearly shown to be unrelated to $L r_{\text {Camayo }}$, the $L r 3$-linked gene located on chromosome $6 \mathrm{BL}(7,10)$. Even though this gene remains effective to date in every location it was tested, including around the Mediterranean Basin, in Eastern Africa, and in South Asia, the discovery of sources different from $L r_{\text {Camayo }}$ is needed to mitigate its extensive deployment in Mexico through the record-yielding, widely grown Cirno C2008 (grown on more than $80 \%$ of the Mexican durum acreage).

Gaza was the only genotype included in this study whose resistance was controlled by two independent genes, one of which was dominant while the other was recessive, one of them being an APR gene and the other one providing seedling resistance. Gaza is known to carry resistance gene $L r 23$, which was also transferred to bread wheat $(16,17)$. At the seedling stage, the IT of the Lr23-carrying line RL6012 was 3+4 (i.e., compatible) when infected with $L r 23$ virulent races (e.g., BBB/BN, BBG/BP, and so on); however, the IT of Gaza with the same races ranged from $3 \mathrm{c}$ to $\mathrm{x}+$, indicating incompatibility. At the adult plant stage, under heavy infection with Lr23-virulent Mexican races, including $\mathrm{BBG} / \mathrm{BP}$, Gaza maintains an IT ranging from traces to $10 \mathrm{M}$. Therefore, neither of the genes detected in the present study can be $L r 23$. This is consistent with the results from Singh et al. (21), who tested differential lines with three different races under two different temperature regimes; they demonstrated that the ITs of Gaza were lower (incompatible) compared with those exhibited by the Lr23-carrying test line RL6012 (compatible). Singh et al. (20) also postulated that Gaza carried Lr23+, indicating the presence of other seedling genes in addition to Lr23. Gaza is reported to be seedling-susceptible to Australian leaf rust pathotype $104-2,3,6,(7)[\mathrm{P} 13 \mathrm{p} 23]$ when incubated at $21^{\circ} \mathrm{C}(17)$, though its adult plant reaction to the same Australian pathotype is unknown (R. A. McIntosh, personal communication).

With the exception of Gaza, all sources were characterized by a simple, monogenic resistance, controlled by either a single recessive gene in the case of Amria and Byblos or a single dominant gene in case of Geromtel_3 and Tunsyr_2. In the case of Geruftel_1, the partial information available did not allow us to draw a decisive conclusion. However, based on the partial information obtained in this study (the seedling ITs similar to those of Geromtel_3, $F_{1}$ field IT, and $F_{2}$ segregation ratio when crossed to Atil*2/Local Red), as well as the pedigree analysis (the two lines share a common parent, D68.1.93A.1A//Ruff/Flamingo/ 3/Omtel_5, which is the most likely source of the resistance), it can be reasonably hypothesized, for practical breeding purposes at least, that Geruftel_1 may share the same resistance gene as Geromtel_3. In fact, allelism testing results suggest that Geromtel_3, Geruftel_1, and Tunsyr_2 may share the same or closely linked resistance gene (no susceptible plants in the $F_{2}$ from intercrosses between the three sources) and that this gene may be closely linked to Lr61 (no susceptible plants detected in the $\mathrm{F}_{2}$ from crosses between the three sources and the Lr61carrieng genotype). Close linkage with Lr61, as opposed to allelism to $L r 61$, is the most likely scenario because all three sources carry a clearly dominantly inherited resistance gene (confirmed by the low ITs of $\mathrm{F}_{1}$ plants), while Lr61 is recessively or partially dominantly inherited (5). On the other hand, the lack of susceptible $\mathrm{F}_{2}$ plants from the crosses between Gaza and either Geromtel_3 or Geruftel_1 suggests an allelic or linkage relationship between one of the genes from Gaza and those of Geromtel_3 and Geruftel_1. However, although the gene from Geromtel_3 and Geruftel_1 (assuming it is the same gene) is likely linked to Lr61, the resistance gene in Gaza is not linked to Lr61, as demonstrated by the number of recombinant susceptible

TABLE 6. Frequencies of resistant and susceptible $\mathrm{F}_{2}$ plants of the crosses of six resistant durum genotypes with 'Cirno C2008' (carrying $L r_{\text {Camayo }}$ ) and line Sooty_9/Rascon_37//Guayacan INIA (carrying Lr61) for allelism testing evaluated under artificially inoculated field conditions with leaf rust (Puccinia triticina) race $\mathrm{BBG} / \mathrm{BP}$ during summer 2012 at El Batan Experimental Station

Number of plants

Cirno C2008 Sooty_9/Rascon_37//Guayacan INIA

\begin{tabular}{|c|c|c|c|c|c|c|}
\hline \multirow[b]{2}{*}{ Parent $^{\mathrm{a}}$} & \multirow[b]{2}{*}{ Total } & & \\
\hline & & Resistant & Susceptible & Total & Resistant & Susceptible \\
\hline Gaza & 273 & 257 & 16 & 177 & 153 & 24 \\
\hline Amria & 286 & 212 & 74 & 310 & 223 & 87 \\
\hline Geromtel_3 & 191 & 164 & 27 & 301 & 301 & 0 \\
\hline Tunsyr_2 & 211 & 176 & 35 & 276 & 276 & 0 \\
\hline Byblos & 193 & 121 & 72 & 280 & 173 & 107 \\
\hline
\end{tabular}

a Resistant parent. 
plants present in the $\mathrm{F}_{2}$ of the cross between Gaza and the Lr61carrying Sooty_9/Rascon_37//Guayacan INIA. One possible scenario that could explain these complex relationships between genes from these four different durum wheat lines is the one in which the gene from Geromtel_3 and Geruftel_1 is physically located between $\operatorname{Lr61}$, possibly located on its distal side because Lr61 is located at the very tip of chromosome 6BS (5), and one of the genes carried by Gaza is located on its proximal side, with the latter located close enough to be closely linked to the Geromtel_3 and Geruftel_1 gene yet far enough from Lr61 to be inherited independently.

In addition, results strongly suggest that the resistance gene from Tunsyr_2 is allelic or tightly linked to that of Geromtel_3 and Geruftel_1 (supported by the fact that all three lines share a common parent) and to Lr61. However, other factors suggest that the resistance of Tunsyr_2 may be different from that of Geromtel_3 and Geruftel_1: with all the avirulent races, Tunsyr_2 produces a mesothetic IT of x while the IT of Geromtel_3 and Geruftel_1 was ;1=. Furthermore, Tunsyr_2 showed a less ambiguous $3 R$ : $1 \mathrm{~S}$ segregation ratio in the $F_{2}$ when crossed with either susceptible parent and, most importantly, its resistance appears to be unrelated to that of Gaza. This could suggest a scenario in which the gene carried by Tunsyr_2 might be located between Lr61 and the gene of Geromtel_3 and Geruftel_1 but distantly enough from the one gene carried by Gaza to be independently inherited from it. In summary, based on all results from the present study and the information available in the literature, it appears that the short arm of chromosome 6B may harbor up to three different genes, in addition to the telomerically located Lr61, in the following order: first, the gene carried by Tunsyr_2; then, the very closely linked gene carried by Geromtel_3 (probably the same as in Geruftel_1); and, finally, closest to the centromere, one of the two genes carried by Gaza. The inter-relationship between these three potentially different genes and their position in relation to Lr61 would require highdensity mapping of the different populations and comparative analysis with already published maps of chromosome 6BS in order to confirm the hypothesized scenario or produce a more likely alternative one (ongoing work). Two other resistance genes have been also mapped to the short arm of chromosome $6 \mathrm{~B}$; namely, Lr36 transferred to hexaploid wheat from T. speltoides (1) and Lr53 introgressed into bread wheat from T. turgidum subsp. dicoccoides (15). No reports are available to indicate that either gene has been transferred to durum wheat. There is no indication in the pedigree of Geromtel_3, Geruftel_1, and Tunsyr_2, tracing three generations back, of any of the hexaploid sources carrying these genes or of any of the wild relatives from which they might have had originated. Therefore, it may be unlikely that the 6BS linked genes from Geromtel_3 and Geruftel_1 or Tunsyr_2 are related to either Lr36 or Lr53. Nevertheless, comparative high-density mapping coupled with multirace leaf rust testing at the seedling stage is needed in order to conclusively eliminate the possibility of any relationship between the 6BS-located genes detected in the present study and Lr36 or Lr53 (ongoing work). This is especially required in relation to the 6BS-located Gaza gene, given the absence of pedigree information for this genotype.

In addition to the existing information $(1,5,15)$, results from the present study highlight the importance of chromosome arm 6BS as a region rich in leaf rust resistance genes, which could be of significant interest in pyramiding multiple genes for durable resistance. In fact, once the number of genes present on this chromosome arm and their order and inter-relationship are elucidated and molecular markers for each of the genes are developed, it should be possible to engineer a 6BS chromosome arm with multiple resistance alleles, several of them being inherited together in a linkage block or with little recombination among them. The relationship between the recessive genes detected in
Amria and Byblos could not be ascertained: making assumptions based on pedigree analysis were not possible because the pedigree of Byblos was not known, and the different seedling ITs of $x$ and $33+$ in Amria and Byblos, respectively (Table 2), with the race $\mathrm{BBG} / \mathrm{BP}$ and somewhat higher adult plant IT of the $\mathrm{F}_{1}$ s involving Byblos may suggest that these two genotypes have a different genetic basis for their resistance to leaf rust. However, neither observation could be considered as conclusive evidence for such a difference. Further allelism testing is required to determine the relationship between the genes from these two genotypes. Although such a relationship remains to be determined, the use of either genotype as a source of alternative resistance genes (i.e., ones that have not been deployed in CIMMYT's breeding program) would be reasonable because they have conclusively been shown to be different from or unrelated to $L r 61, L r_{\text {Camayo }}$, $L r 14 a$, and $L r 3$ in addition to being different from those other resistance sources characterized in the present study.

In conclusion, the present characterization of the inheritance of leaf rust resistance in six globally resistant durum wheat sources has resulted in the detection of at least three and possibly up to five different genes likely to be different from those routinely used in CIMMYT's breeding program. One of these is an unreported gene from the Middle-Eastern landrace Gaza. One, possibly two, recessive genes were detected in Moroccan Amria and in French Byblos. Finally, a group of at least two genes likely linked to Lr61 on chromosome arm 6BS have been detected again in Gaza (at least one of the two genes detected) and in lines Geromtel_3, Geruftel_1, and Tunsyr_2, with a possibility that the gene from Tunsyr_2 may be different from though closely linked to that of Geromtel_3 and Geruftel_1. These results warrant the continued genetic characterization of at least five of these durum genotypes and the ongoing high-density mapping of the corresponding populations to elucidate the relationship between the genes detected as well as develop closely linked markers for each.

\section{ACKNOWLEDGMENTS}

The present work has been made possible thanks to funding from "Patronato por la Investigación y Experimentación Agrícola del Estado de Sonora (PIEAES)"/Fundacíón Produce Sonora, México, and the "Durable Rust Resistance Wheat (DRRW)" Project as part of the Borlaug Global Rust Initiative (BGRI). We thank P. Singh (CIMMYT) for his critical review of the manuscript.

\section{LITERATURE CITED}

1. Dvořák, J., and Knott, D. 1990. Location of a Triticum speltoides chromosome segment conferring resistance to leaf rust in Triticum aestivum. Genome 33:892-897.

2. Gharbi, M.S., Ammar, K, Berrias, S., Karboul, K., and Manel, A. 2013. Mitigating the threat of leaf rust to durum yield stability in new Septoria tritici blotch resistant germplasm in Tunisia. In: Proc. BGRI Tech. Workshop, New Delhi, India.

3. Goyeau, H., Ammar, K., and Berder, J. 2010. Virulence in Puccinia triticina for durum wheat cultivar Creso and other durum wheat cultivars carrying resistance gene Lr14a in France. Plant Dis. 94:1068-1068.

4. Goyeau, H., Park, R., Schaeffer, B., and Lannou, C. 2006. Distribution of pathotypes with regard to host cultivars in French wheat leaf rust populations. Phytopathology 96:264-273.

5. Herrera-Foessel, S., Singh, R., Huerta-Espino, J., William, H., Djurle, A., and Yuen, J. 2008. Molecular mapping of a leaf rust resistance gene on the short arm of chromosome 6B of durum wheat. Plant Dis. 92:1650-1654.

6. Herrera-Foessel, S., Singh, R., Huerta-Espino, J., William, H., Garcia, V., Djurle, A., and Yuen, J. 2008. Identification and molecular characterization of leaf rust resistance gene $L r 14 a$ in durum wheat. Plant Dis. 92:469-473.

7. Herrera-Foessel, S., Singh, R., Huerta-Espino, J., Yuen, J., and Djurle, A. 2005. New genes for leaf rust resistance in CIMMYT durum wheats. Plant Dis. 89:809-814.

8. Herrera-Foessel, S. A., Huerta-Espino, J., Calvo-Salazar, V., Lan, C., and Singh, R. P. 2013. Lr72 confers resistance to leaf rust in durum wheat 
cultivar 'Atil C2000'. Plant Dis. 98:631-635.

9. Herrera-Foessel, S. A., Singh, R. P., Huerta-Espino, J., Crossa, J., Djurle, A., and Yuen, J. 2008. Genetic analysis of slow-rusting resistance to leaf rust in durum wheat. Crop Sci. 48:2132-2140.

10. Herrera-Foessel, S. A., Singh, R. P., Huerta-Espino, J., William, M., Rosewarne, G., Djurle, A., and Yuen, J. 2007. Identification and mapping of $L r 3$ and a linked leaf rust resistance gene in durum wheat. Crop Sci. 47:1459-1466.

11. Huerta-Espino, J., Singh, R., Germán, S., McCallum, B., Park, R., Chen, W., Bhardwaj, S., and Goyeau, H. 2011. Global status of wheat leaf rust caused by Puccinia triticina. Euphytica 179:143-160.

12. Huerta-Espino, J., Singh, R., Herrera-Foessel, S., Perez-Lopez, J., and Figueroa-López, P. 2009. First detection of virulence in Puccinia triticina to resistance genes $L r 27+L r 31$ present in durum wheat in Mexico. Plant Dis. 93:110.

13. Maccaferri, M., Mantovani, P., Tuberosa, R., DeAmbrogio, E., Giuliani, S., Demontis, A., Massi, A., and Sanguineti, M. 2008. A major QTL for durable leaf rust resistance widely exploited in durum wheat breeding programs maps on the distal region of chromosome arm 7BL. Theor. Appl. Genet. 117:1225-1240.

14. Maccaferri, M., Sanguineti, M. C., Mantovani, P., Demontis, A., Massi, A., Ammar, K., Kolmer, J. A., Czembor, J. H., Ezrati, S., and Tuberosa, R. 2010. Association mapping of leaf rust response in durum wheat. Mol. Breed. 26:189-228.
15. Marais, G., Pretorius, Z., Wellings, C., McCallum, B., and Marais, A. 2005. Leaf rust and stripe rust resistance genes transferred to common wheat from Triticum dicoccoides. Euphytica 143:115-123.

16. McIntosh, R., and Dyck, P. 1975. Cytogenetical studies in wheat VII. Gene Lr23 for reaction to Puccinia recondita in Gabo and related cultivars. Aust. J. Biol. Sci. 28:201-212.

17. McIntosh, R. A., Wellings, C. R., and Park, R. F. 1995. Wheat Rusts: An Atlas of Resistance Genes. Commonwealth Scientific and Industrial Research Organization, Australia, and Kluwer Academic Publishers, Dordrecht, The Netherlands.

18. Peterson, R. F., Campbell, A., and Hannah, A. 1948. A diagrammatic scale for estimating rust intensity on leaves and stems of cereals. Can. J. Res. Sect. C 26:496-500.

19. Singh, R., Bechere, E., and Abdalla, O. 1993. Genetic analysis of resistance to leaf rust in nine durum wheats. Plant Dis. 77:460-463.

20. Singh, R., Huerta-Espino, J., Pfeiffer, W., and Figueroa-Lopez, P. 2004. Occurrence and impact of a new leaf rust race on durum wheat in northwestern Mexico from 2001 to 2003. Plant Dis. 88:703-708.

21. Singh, R., and McIntosh, R. 1984. Complementary genes for reaction to Puccinia recondita tritici in Triticum aestivum. I. Genetic and linkage studies. Can. J. Genet. Cytol. 26:723-735.

22. Singh, R., and McIntosh, R. 1984. Complementary genes for reaction to Puccinia recondita tritici in Triticum aestivum. II. Cytogenetic studies. Can. J. Cytol. 26:736-742. 